\title{
When the trade winds blow in our favor
}

\author{
by Paul McKellips
}

Christopher Columbus was not a wealthy man. But he had an idea, one that required substantial funding, great risk, unparalleled innovation and relentless work.

Columbus was wrong about a lot of things. He inaccurately calculated how many degrees of longitude separated Europe from the Far East. And he was wrong about the distance each degree actually represented. He incorrectly estimated that the voyage between the Canary Islands off the northwest coast of Africa and Japan would be about 2,300 statute miles. It was actually 12,200 statute miles. No ship in the 15 th century could carry enough food and fresh water for a voyage of that length.

But his knowledge and hypotheses about the trade winds were completely correct.

With the fall of Constantinople to the Ottoman Turks in 1453, safe-land passage along the Silk Road for trade with Asia became more dangerous. The people needed a solution. Bartolomeu Dias had successfully sailed south to the Cape of Good Hope in South Africa, but Columbus had a different idea-to sail west across the Ocean Sea to find what is now Japan.

In 1485, Columbus took his idea to King John II of Portugal and asked for three sturdy ships and one year to sail to the Orient and back. His funding request was denied because King John's committee of experts deemed that Columbus was wrong with his mileage calculations.

In 1486, Columbus took his idea to King Ferdinand II of Aragon and Queen Isabella I of Castille. Isabella sent Columbus and his idea to various committees where they languished for years.

In 1488, Columbus went back to King John and asked Portugal to reconsider funding his idea. But after Dias returned to Portugal with news that a successful rounding of the southern tip of Africa had

McKellips is Executive Vice President of the Foundation for Biomedical Research in Washington, DC. occurred and an eastern sailing route to Asia was possible, King John was no longer interested in Columbus or his ridiculous hypothesis.

Undeterred, Columbus went to Genoa and Venice looking for funding. He was denied by both. Columbus sent his brother

\section{Discovery is a product \\ of tenacity.}

Bartholomew to England but the court of King Henry VII was not the least bit interested in financing his request either.

Finally, in 1492, concerned that Columbus might take his far-fetched project to a different and perhaps competing kingdom, and after two more years of negotiations and discussions, the Spanish court agreed to fund Columbus's journey.

But Spain quickly depleted its national treasury in the Granada campaign, and Isabella cancelled the Columbus voyage due to a lack of funds. King Ferdinand stepped in after a dejected Columbus had already left the Spanish court on the back of a mule. Funds were shifted around in Spain, and Columbus raised half of the needed money from Italian investors.

On 3 August 1492, the Santa Clara (nicknamed the Nina in honor of her owner, Juan Nino), the Pinta and the Santa Maria set sail from Palos de la Frontera, a small seaside town in the Spanish province of Huelva, for Japan.

The rest, as they say, is history. And history teaches us some great lessons.

First, if all of our assumptions were correct and our hypotheses were flawless and accurate, then there would be no need for discovery.

Second, exploration and innovative ideas need funding. Columbus had an idea that was larger than his own personal bank account. He needed financial help to test his theories and prove the concepts.
Third, the best source of funding may be the government because the spoils of discovery belong to the people who helped finance the exploration. But Columbus knew that he needed private sector help as well, so he raised half of the money for his exploration from individual investors.

And fourth, discovery is a product of tenacity. Columbus and his brother were rejected numerous times by Portugal, Genoa, Venice, England and Spain. Columbus took every 'no' to mean he was that much closer to a 'yes.' I suspect that even while riding on his mule and long before Ferdinand and Isabella's messengers reached him and turned that jackass around, Columbus was plotting who he might contact next.

Even in the face of a depleted Spanish treasury, Columbus refused to quit. Even though Dias had found a different route, an acceptable route, Columbus refused to quit.

Five hundred and twenty-one years later, the American treasury is depleted, and a jobless economic recovery sputters along like a mule. Biomedical researchers and scientists with great ideas have knocked on the doors of government, and the court jesters and their grand sequester have drastically reduced funding for the voyages of basic science discovery.

Perhaps they think our assumptions are incorrect and our hypotheses are flawed. But though we may be dejected like Columbus, perhaps all of us should get off of our asses and keep calling on the government and shouting our ideas. For if they knew that in our ideas we see cures for cancer, treatments for Alzheimer's and breakthroughs for dreadful conditions, perhaps they, too, would shift some funds around just as Isabella did.

We may have some things wrong. But our best and brightest minds understand the trade winds. And the rest, as they say, can be our history as well. 